\title{
21. Seclusion versus Accessibility: The Harems of Constantinople as Aesthetic Worlds in Stories by Elsa Lindberg-Dovlette
}

Helena Bodin

Comparative Literature, Stockholm University

At the turn of the twentieth century, the harem was still a secluded and concealed space, unknown to most westerners and therefore arousing their curiosity. Novels about life in a harem, such as Pierre Loti's Les Désenchantées (I906), ${ }^{\mathrm{I}}$ set in cosmopolitan Constantinople, were bestsellers and widely translated in the early twentieth century. Likewise, for several decades, descriptions of visits to Turkish harems had been essential elements in travelogues about Constantinople by female writers such as the Englishwoman E. C. C. Baillie and the Danish Elisabeth Jerichau Baumann, ${ }^{2}$ while motifs from harems, painted by such artists as

\footnotetext{
I Pierre Loti, Les Désenchantées: Roman des harems turcs contemporains (Paris: Calmann-Lévy, I906).

2 E. C. C. Baillie, A Sail to Smyrna: Or, an English Woman's Journal; Including Impressions of Constantinople, a Visit to a Turkish Harem, and a Railway Journey to Ephesus ... (London: Longmans, Green, and Co., I 873), I65-99, as mentioned by Mary Roberts, Intimate Outsiders: The Harem in Ottoman and Orientalist Art and Travel Literature (Durham: Duke University Press, 2007), 62-63; Elisabeth Jerichau-Baumann, Brogede rejsebilleder (Kjøbenhavn: Forlagsbureauet, I88I), esp. 20-28, discussed by Elisabeth Oxfeldt, Journeys from Scandinavia: Travelogues
}

How to cite this book chapter:

Bodin, Helena. "Seclusion versus Accessibility: The Harems of Constantinople as Aesthetic Worlds in Stories by Elsa Lindberg-Dovlette". In World Literatures: Exploring the Cosmopolitan-Vernacular Exchange, edited by Stefan Helgesson, Annika Mörte Alling, Yvonne Lindqvist, and Helena Wulff, 246-260. Stockholm: Stockholm University Press, 20I 8. DOI: https:// doi.org/Io.I6993/bat.u. License: CC-BY. 
Osman Hamdi Bey and John Frederick Lewis, were extremely popular.

This chapter focuses on stories by the Swedish author Elsa Lindberg-Dovlette (I876-I944), in which life in the Ottoman harems of Constantinople in the early twentieth century is portrayed from the perspective of female insiders. These stories provide an example of the particular intersection of the Swedish and Turkish languages and cultures in Constantinople, as well as of Christian and Muslim beliefs, with special regard to the situation of women. As will be demonstrated, the "world-making" of these stories is informed by the limited and distorted perspective both from inside the harem and from behind the veil, but simultaneously also by the distinctive perspective of a young and - as it seems - emancipated Swedish woman, voluntarily living in a traditional Turkish harem. Although the notion of harem often activates a whole complex of ideas about veiled women, eunuchs, seclusion and polygamy, it does not necessarily imply polygamy but rather designates basically domestic spaces reserved for women in Muslim cultures, spaces found also in trains and boats. ${ }^{3}$

There are three such books by Lindberg-Dovlette on life in the harems of Constantinople. The first is a collection of eight short stories, Kvinnor frän minareternas stad (1908; Women from the city of minarets), illustrated by portraits in India ink by Isaac Grünewald. The next is a novel, Främling (I924 and I929; Stranger), of which the second edition is illustrated in bright colours by Einar Nerman, inspired by orientalist imaginings, which appeared in a series described by the publisher as gift novels "by the foremost Swedish women writers". Its sequel is also a novel, Bakom stängda haremsdörrar (I93 I; Behind the closed doors of the harem). The protagonists of the novels are two young women: the Swedish Astrid, who is renamed Anisa [Enise] when she marries a Turkish pasha and enters his harem, and the Turkish

of Africa, Asia, and South America, I840-2000 (Minneapolis: University of Minnesota Press, 2010), 3I-57.

3 Fadwa El Guindi, Veil: Modesty, Privacy and Resistance (Oxford: Berg, I999), 3-I 2. 


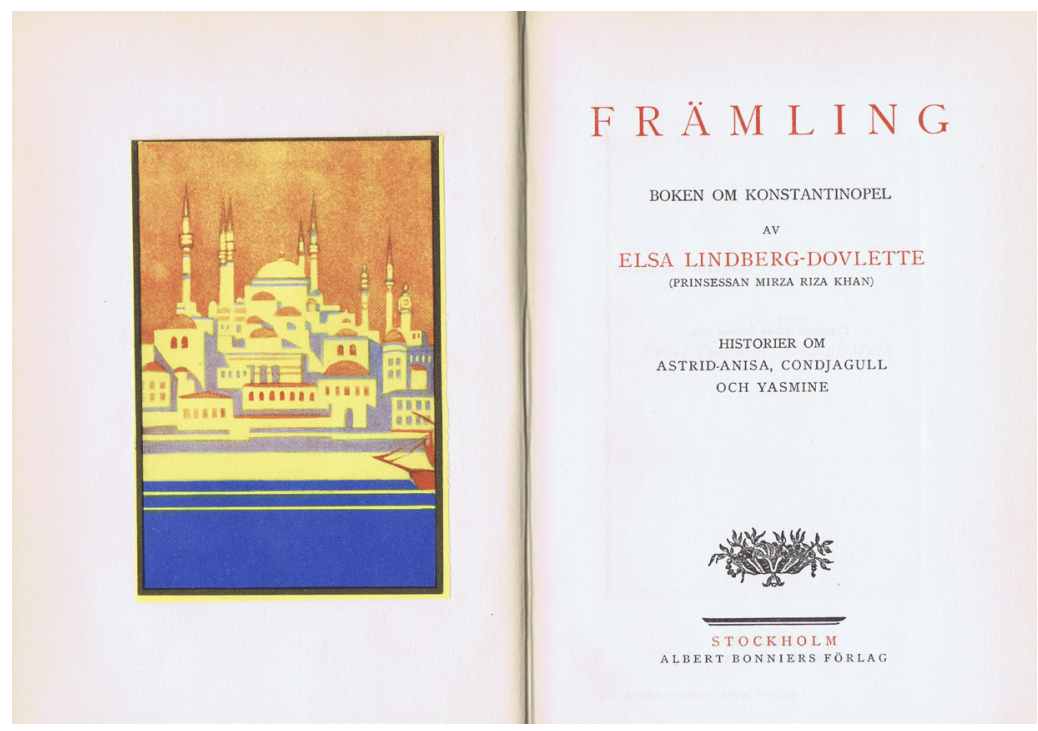

Figure 3. Title page of the second edition of Elsa Lindberg-Dovlette's Främling (I929; Stranger), illustrated by Einar Nerman. Copyright: Helena Bodin. License: CC BY.

Condjagull [Goncagül], who is raised in the same harem and is blind.

Lindberg-Dovlette renders various words, phrases and names in Turkish (transcribed into Roman letters according to Swedish pronunciation standards), together with translations into Swedish, occasionally with explanatory footnotes. ${ }^{4}$ Such devices add a certain anthropological and documentary touch to these quite traditionally narrated, romantic stories of love, suffering, violence and death, which also owe something to fairy tales inspired by the Arabian Nights, especially because of their orientalising illustrations. Lindberg-Dovlette's knowledge of Turkish and of harem life has an autobiographical background: In I902, she married a Persian diplomat and prince, Mirza Riza Khan Arfa (Arfa'-al-Dawla), and

4 See Helena Bodin, “'Mai vite dale svenske'. Konstantinopels mångspråkighet i skandinavisk litteratur kring I900”, Dragomanen I9 (2017): IOO-IO2. 
lived in his harem in Constantinople as his sole wife, where she gave birth to two children. As a reminder of these circumstances, apparently, the covers and title pages of the novels are adorned with Persian and Arabic calligraphy. Her extraordinary life story attracted much public attention, and although she is generally forgotten today, she was a productive and appreciated journalist and writer in both Sweden and Finland. ${ }^{5}$

\section{World-Making}

By applying Eric Hayot's ideas as formulated in On Literary Worlds (2OI2), this chapter will examine aspects of character systems and connectedness as the strategies according to which Lindberg-Dovlette's stories create a distinctive aesthetic world. Drawing on Martin Heidegger in his Der Ursprung des Kunstwerkes, Hayot uses "world" (Welt) as a verb, indicating a process, an activity. His point is that there is a continuous worlding going on in literary works, thereby forming different aesthetic worlds: "Aesthetic worldedness is the form of the relation a work establishes between the world inside and the world outside the work". ${ }^{6}$ These aesthetic worlds can be mapped and characterised from certain given aspects, including the examination of a work's character system by measuring the characters' "access to privileged narrative markers", 7 such as their access to direct speech and focalisation or their importance to the plot, while connectedness describes to what extent a particular aesthetic world is connected with or disconnected from other worlds. More generally, Hayot's approach implies the possibility of fruitfully reading and

5 Henrika Zilliacus-Tikkanen, "Elsa Lindberg-Dovlette", in När Könet började skriva: Kvinnor $i$ finländsk press I77I-I900 (Helsingfors: Finska vetenskaps-Societeten, 2005), I38-44. For Elsa LindbergDovlette's life and hyphenated identity, see Helena Bodin, "Haremslivet i Konstantinopel i berättelser av Elsa Lindberg-Dovlette”, Tijdschrift voor Skandinavistiek 36 (2018): 2, I08-16.

${ }^{6}$ Eric Hayot, On Literary Worlds (Oxford: Oxford University Press, 20I2), 45 .

7 Hayot, On Literary Worlds, 79. 
interpreting "the world" as an immanent aspect of the literary text and not only as its external, contextual aspect.

Harems, and their representations in literature and art, often in connection with the topic of veiling, form an obvious and important part of studies of orientalism, inspired by the postcolonial perspective of Edward W. Said's seminal work of $1978 .{ }^{8}$ Harems and veiling practices have been widely researched within various disciplines, such as history and anthropology, and, as an artistic or literary motif, in postcolonial and gender studies. ${ }^{9}$ They have also been studied from the perspective of national cultures, where especially British orientalism has often been the focus. ${ }^{\text {I0 }}$ Several important studies have been anthologised by Marilyn Booth in Harem Histories (2010). ${ }^{\text {II }}$ Recently too, the Afghan photographer Sulaiman Edrissy has cross-dressed as a woman wearing a burka in order to explore in photographs the obscured view of the world from behind or inside the veil - a similar venture as that pursued by Lindberg-Dovlette in the early twentieth century, though by means of a different medium. ${ }^{12}$ However, when studying older artefacts or literary texts such as Lindberg-Dovlette's stories, it is important to also consider John M. MacKenzie's criticism of Edward Said's concept of orientalism. As MacKenzie points out, the meaning and connotations of orientalism have differed with

${ }^{8}$ Edward W. Said, Orientalism (London: Routledge \& Kegan Paul, I978).

9 See for example Leslie P. Peirce, The Imperial Harem: Women and Sovereignty in the Ottoman Empire (Oxford: Oxford University Press, I993); Lila Abu-Lughod, Veiled Sentiments: Honor and Poetry in a Bedouin Society (Berkeley: University of California Press, I999); El Guindi, Veil; Emily Apter, Continental Drift: From National Characters to Virtual Subjects (Chicago: University of Chicago Press, I999); Reina Lewis, Rethinking Orientalism: Women, Travel and the Ottoman Harem (London: I. B. Tauris, 2004); Jennifer Heath, ed., The Veil: Women Writers on Its History, Lore and Politics (Berkeley: University of California Press, 2008).

Io Roberts, Intimate Outsiders; Zeynep İnankur, Reina Lewis, and Mary Roberts, eds., The Poetics and Politics of Place: Ottoman Istanbul and British Orientalism (İstanbul: Pera Museum, 20I I).

${ }^{\prime}$ Marilyn Booth, ed., Harem Histories: Envisioning Places and Living Spaces (Durham: Duke University Press, 2010).

I2 Sulaiman Edrissy, Burqa Web, http://imgur.com/a/Idjzf. 
regard to space and time, and "contemporary attitudes and prejudices" should therefore not be read back into historical periods. He emphasises the importance of an appropriate historical and cultural contextualisation, and warns against "techniques of cultural cross-referencing" which risk missing complexities and tend to be ahistorical. ${ }^{13}$ This is particularly true in relation to stories about harems and veiling practices, since they have never been homogeneous but have conveyed different meanings in different regions and eras. Veiling in the late twentieth century may have, for example, other reasons and connotations from at the beginning of the century. ${ }^{\mathrm{I} 4}$

What interests me in Lindberg-Dovlette's stories is how the secluded milieus of harems in cosmopolitan early twentieth-century Constantinople are made accessible to western readers in their vernacular languages, not only in Swedish, but also in translation into Finnish, German, French and Dutch. Readers are thereby allowed to experience the limited view and reduced mobility of women in the harem as if from the inside. The stories are set during the reign of Abdülhamid II, before I909, while the harems themselves were questioned, dissolved and finally forbidden in Turkey shortly afterwards under Atatürk in the I920s. Also, this was the time when women were struggling for - and received - suffrage, in Sweden in I9I9 and in Turkey in I934. As we will see, these stories comment implicitly, but in particular cases also explicitly, on the political situation of women in both Turkey and Sweden. On yet another level, they reflect the obscured and distorted worldview of westerners producing and enjoying stories and paintings about harems. Issues of seeing - or rather issues of unseeing and blindness - connected with veiling practices, thematised in these stories and emphasised in some of the illustrations, will therefore be central to my analysis and discussion, while the concept of "seeing" will be operationalised as an analytical tool. Similar issues of seeing and perspective form the centre of attention in Mary Roberts's study of earlier travelogues by British women in

${ }^{13}$ John M. MacKenzie, Orientalism: History, Theory and the Arts (Manchester: Manchester University Press, I995), 2 I4, xxi, xvii.

${ }^{14}$ See further El Guindi, Veil, esp. at 3-I2 and I77-86. 
the chapter "Being Seen" in Intimate Outsiders (2007), ${ }^{\mathrm{I}}$ which will therefore be the starting point for my analysis, before introducing aspects of literary world-making as perceived by Hayot.

\section{Observation and Confrontation}

In contrast to men (except the husband), all women, including westerners, were allowed to enter the harem. Mary Roberts has found that women's travelogues generate a different kind of orientalist fantasy, experienced from inside the harem, from men's "voyeuristic images of the harem that emphasised the western viewer's fantasy of looking without being observed". ${ }^{16}$ Her point is that western female visitors themselves became confronted by women in the harem and exposed to their straightforward opinions and active, interrogative stare. While the male gaze traditionally commanded the visual field, women could bear witness to fear, because of their sense of being watched and "simultaneously subject and object of the look".${ }^{17}$ By being observed by the women in the harem, the western woman was enabled "to see herself in the harem by being seen". ${ }^{18}$

At first glance, the conclusion drawn by Roberts seems to be valid also with regard to the stories by Elsa Lindberg-Dovlette. In the opening short story, for example, there is the young Turkish female narrator, who repeatedly addresses the reader personally as "my foreign friend" ("min främmande vän"), ${ }^{19}$ thereby inviting the reader to take a walk through Constantinople: "Come with me, you, my foreign friend!" ("Kom med mig du, min främmande vän!" $)^{20}$ But the reader is also told to be grateful that she does not have to dress in a veil, since the veil turns all faces pale and all

\footnotetext{
${ }_{15}$ Roberts, Intimate Outsiders, 80-91.

${ }^{16}$ Roberts, Intimate Outsiders, 82.

${ }_{17}$ Roberts, Intimate Outsiders, 86.

I8 Roberts, Intimate Outsiders, 90.

19 Lindberg-Dovlette, Kvinnor $i$ minareternas stad (Stockholm: Bonniers, I908), 4. All translations from Lindberg-Dovlette's works are my own.

${ }^{20}$ Lindberg-Dovlette, Kvinnor i minareternas stad, 22.
} 
eyes sad. ${ }^{21}$ Also, the Swedish protagonist of the two later novels, Astrid, is amicably welcomed into the harem, on the one hand, by the blind Condjagull, but is treated on the other as a stranger by the evil and jealous Yasmine, her antagonist. ${ }^{22}$ Furthermore, it is impossible for Astrid to feel comfortable wearing the veil: "To look out on the world through a thick black veil, that is like seeing everything through tears" ("Att se ut på världen genom en tät svart slöja, det är som att se på allt genom tårar"). ${ }^{23}$ In this way, both the reader and the Swedish protagonist are kindly invited to take part in daily harem life in Constantinople. But at the same time, the protagonist is treated and behaves like a stranger, who is observed and confronted by the women in the harem, and sometimes even makes protests or shows her own dislike of the restrictions imposed on women. The following analysis, where Hayot's ideas of character system and connectedness are examined, will show, however, that issues of seeing and perspective are even more complex in Lindberg-Dovlette's stories on Constantinople and its harems than in the cases described by Roberts. They are not only thematised by Lindberg-Dovlette but decisive for the total construction of this aesthetic world, characterised by seclusion, flickering light, darkness and various severe limitations on both vision and mobility.

\section{Character System and Connectedness}

The character system of Lindberg-Dovlette's stories constructs a women's world, where the female characters are the important ones as regards their allotted space for speaking and reflecting in dialogues and descriptions. Women are also the driving force when it comes to action. All kinds of actions - grounded in respectful honour, loving helpfulness, malicious incantations and open hatred - take place between women, as does that particular

${ }_{21}$ Lindberg-Dovlette, Kvinnor i minareternas stad, 23.

22 Elsa Lindberg-Dovlette, Bakom stängda haremsdörrar (Stockholm: Bonniers, I93 I), 95.

${ }^{23}$ Elsa Lindberg-Dovlette, Främling. Boken om Konstantinopel. Historier om Astrid-Anisa, Condjagull och Yasmine (Stockholm: Bonniers, I929 [I924]), I 27. 
kind of eroticism and intimate depiction of feminine charms traditionally associated with harems.

The aesthetic world created by Lindberg-Dovlette is thus maintained by the female characters, by their actions, dialogues, reflections and desires. When it comes to the aspect of connectedness, however, the harem may seem to be disconnected from other, surrounding worlds, since the characters often reflect on how confining the barred harem windows and the veil are, how limited the field of vision becomes for the women in the harem, and how hard it is to move swiftly and sure-footedly when wearing a veil. Since the narrative point of view is theirs, it follows that the limitations to their field of vision crucially affect this aesthetic world. It becomes as narrow as the women's perspective is limited by the barred windows and the veil. This complication is also developed by the artist Isaac Grünewald in black India ink drawings, illustrating Lindberg-Dovlette's short stories, where concealing veils and sometimes window lattices are included as stylised parts of his portraits of the female protagonists. That the novels' Turkish protagonist Condjagull is born in the harem and gradually loses her sight only to become totally blind before the age of marrying, strengthens further this theme in a symbolic way.

Inside the harem, the view is limited because of the characteristic windows, which are covered by a type of wooden lattice that prevents women from being viewed from the outside and creates a special flickering light indoors. However, as the Swedish AstridAnisa observes, it is possible to look out through the lattice. But to do so, she has to press her forehead against the wooden slats, and then the view becomes cut into small pieces. She compares the distorted view to a jigsaw puzzle. ${ }^{24}$

Views from the harem are also limited because of the surrounding walls containing locked gates. In Lindberg-Dovlette's stories, these gates and doors always have more than one lock, of which the keys are carefully guarded. One of the short stories describes how the door to the harem may be transformed: Once the wedding contract is signed, the door closes, and thereafter, it is "no

\footnotetext{
${ }^{24}$ Lindberg-Dovlette, Främling, I 55 .
} 


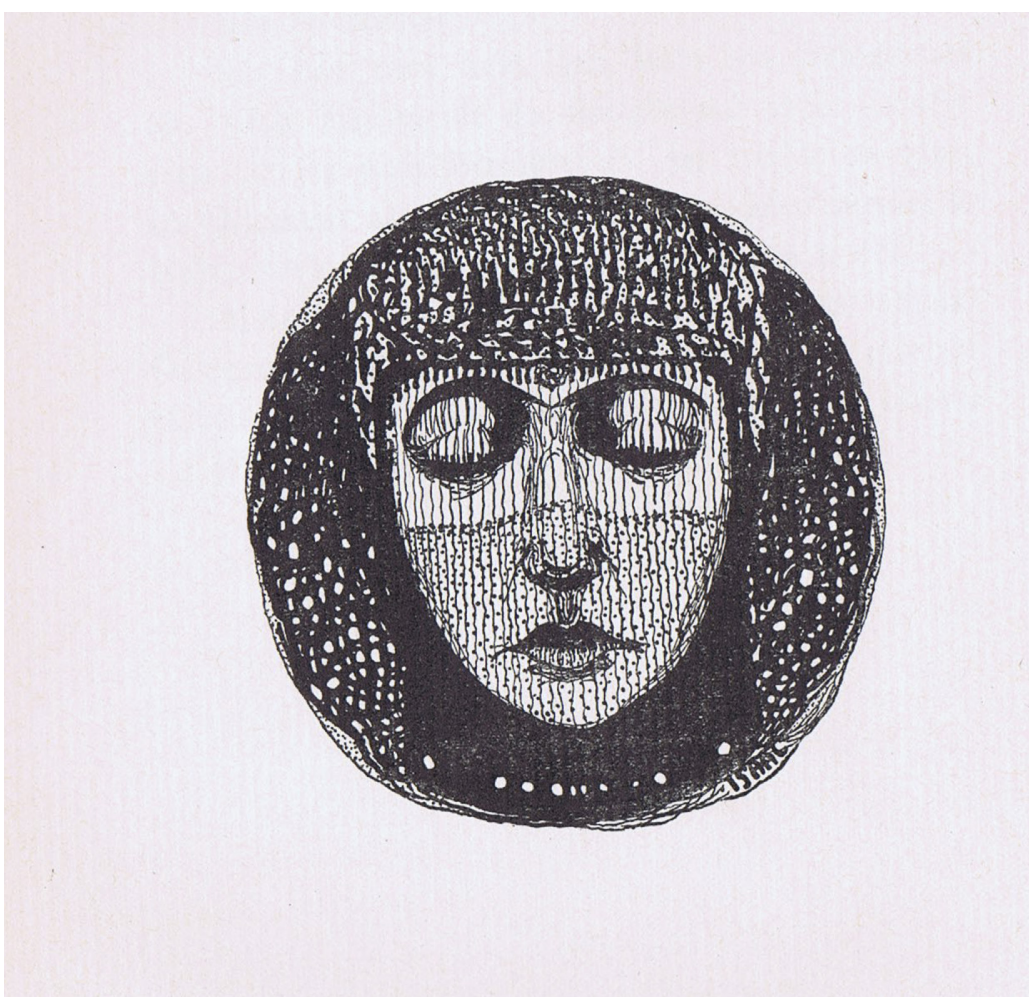

Figure 4. Vignette in India ink by Isaac Grünewald, illustrating Elsa Lindberg-Dovlette's short story "Skepp, som segla förbi” (Ships passing by) in Kvinnor frain minareternas stad (1908; Women from the city of minarets), p. II6. License: public domain.

more the light harem door of childhood" ("icke barndomens lätta haremsdörr"), but a door belonging to the husband and master, a door with heavy hinges and many locks. ${ }^{25}$

If women need to go outside the harem, they have to be covered all over, according to law. As the female Turkish narrator in Lindberg-Dovlette's opening short story complains, it is not only a matter of being veiled but also of not being allowed by the police to stroll about the streets or to enjoy the beautiful light,

${ }_{25}$ Lindberg-Dovlette, Kvinnor i minareternas stad, 105. 
colours and fresh air from the bridge. She has to move on straight ahead to her goal with her black veil turned down, preventing her from seeing clearly. ${ }^{26}$ Another example may be found in the episode where Astrid-Anisa accompanies the blind Condjagull to her wedding. They travel in a carriage in which it is completely dark, like in a closed box, because of its covered windows. While the Swedish girl feels depressed in the darkness, the bride herself notices no difference between travelling in bright daylight or in a blacked-out carriage, because of her blindness, which especially in this case once again acquires symbolic significance. ${ }^{27}$

In spite of these difficulties, there are women in LindbergDovlette's stories who deliberately leave the harem, trying to escape its enclosure. But when they change their minds and want to return to the harem, they are not let in. Their escape leads thus only to homelessness. Outside the harem, they face death, not because of sentences passed against them, but due to circumstances such as drowning or freezing to death. For the Swedish Astrid, this works however the other way round: She dies when she enters the harem and is renamed Anisa. Her husband declares, "Astrid is no more" ("Astrid finnes ej mer"), and she herself mourns Astrid as if dead - without being buried, Astrid has been obliterated. ${ }^{28}$

According to these examples, the aesthetic world of the harem in Lindberg-Dovlette's stories seems to be a disconnected one, enclosed by shutters, locked doors and turned-down veils. If a woman ventures nevertheless to use its openings in order to exit or enter, she is not transported into another world, as in the literary genre of fantasy, but most probably encounters death - physically or socially, through an irretrievable loss of identity. A potential opening in this aesthetic world does not therefore mean any new opportunity for the woman who tries it, but only her end.

Yet this aesthetic world does connect with the surrounding world: from the inside of the harem. Since Lindberg-Dovlette's stories are set in Constantinople in the early twentieth century,

\footnotetext{
${ }^{26}$ Lindberg-Dovlette, Kvinnor i minareternas stad, I9.

27 Lindberg-Dovlette, Bakom stängda haremsdörrar, I 27.

${ }_{28}$ Lindberg-Dovlette, Främling, 6I and I 54.
} 
they portray not only traditional Turkish ways of living, but also the heavy influence on life in the harems of western, particularly Parisian customs, fashion and education. For decades, there had been western governesses residing in harems who taught the girls reading, writing and how to speak French and English. Women in the harems played the piano and practised singing, dressed in Parisian fashions and furnished their bedrooms in the western style; they were also eager to have their portraits painted or be photographed - while all these activities have often been elaborated on in harem novels and travelogues. According to LindbergDovlette's novels, it was of great importance for noble Turkish girls in the harems to be "tjock à la franka" [çok alafranga], translated in a footnote as "Just like in Europe" ("Alldeles som i Europa"). ${ }^{29}$ Hence there was a large English gilded bed in the blind girl's bedroom, even if she could not see it and never slept in it. The western influence on life in the harems also explains how Astrid-Anisa was able to communicate with her - both of them knew French.

The connections between the aesthetic world of the harem in Lindberg-Dovlette's stories and the surrounding world are consistently sustained by western governesses, who teach girls western European languages and arts (including fashion, design and furnishing) in the harems, not by moving about freely outside the harems or by opening their windows and doors. From an anthropological perspective, the governesses and teachers function in these cases as cultural brokers, while the inner world of the harem, rich in linguistic and artistic skills, may be likened to a cultural enclave - it neither connects with, nor influences the prevailing norms and values of the surrounding Ottoman society. The conflicts between western (Christian) and eastern (Muslim) practices are therefore numerous in Lindberg-Dovlette's stories and characterise their aesthetic world. ${ }^{3 \circ}$

29 Lindberg-Dovlette, Främling, 208.

30 For examples, see Bodin, "Haremslivet i Konstantinopel". 


\section{Conclusion}

Inspired by Eric Hayot's thoughts on literary worlds and aspects of his idea of "worldedness" in literature, my analysis has demonstrated that Elsa Lindberg-Dovlette's stories set in the harems of Constantinople create an aesthetic world, wherein western readers can experience the special limited view and reduced mobility of the women living in them. This is accomplished by means of the character system of these stories, where women are the speaking, reflecting and acting protagonists, as well as by means of the special treatment of connectedness, where an outer, far-reaching disconnection with the surrounding world is complicated by inner, extensive connections with western Europe, its languages, arts and fashions. Although the harem in the aesthetic world created by Lindberg-Dovlette has certain connections with the surrounding world, women who pass through the walls of the harem - in either direction - risk their lives or identities. When the characters enter the harem or don the veil, it is not simply a matter of women observing each other from different perspectives, but rather of seeing itself, that is of the women's possibility to see and thereby partake in the surrounding world, that changes and becomes reduced, distorted and sorrowful. This makes Lindberg-Dovlette's stories different from the depictions of harems that Mary Roberts has studied in British women's travelogues.

In the aesthetic world of Lindberg-Dovlette, life conditions in the harem are portrayed from the twofold critical perspective of a Swedish woman. Although she has voluntarily become an insider, she laments the limitations imposed on her field of vision by the harem shutters and the veil, as well as the situation of Turkish women longing to enjoy mobility and open prospects. Elsa Lindberg-Dovlette's stories thereby offer a strong critique of the norms of harem life, but the strength of their argument lies not primarily in the discussions and reflections that are explicitly articulated by the female characters, but rather in their aesthetic world as a whole, constructed out of limited and distorted views. Above, I referred to Hayot's words that aesthetic "worldedness" implies a relation "between the world inside and the world outside the work". My conclusion on the aesthetic world of LindbergDovlette is that it makes the seclusion of women in the harems of 
Constantinople accessible to all readers of her stories, men and women alike.

\section{Bibliography}

Abu-Lughod, Lila. Veiled Sentiments: Honor and Poetry in a Bedouin Society. Updated edition. Berkeley: University of California Press, I999 [1986].

Apter, Emily. Continental Drift: From National Characters to Virtual Subjects. Chicago: University of Chicago Press, I999.

Baillie, E. C. C. A Sail to Smyrna: Or, an English Woman's Journal; Including Impressions of Constantinople, a Visit to a Turkish Harem, and a Railway Journey to Ephesus... London: Longmans, Green, and Co., I873.

Bodin, Helena. “'Mai vite dale svenske'. Konstantinopels mångspråkighet i skandinavisk litteratur kring I900”. Dragomanen I9 (2017): 88-I03.

—. "Haremslivet i Konstantinopel i berättelser av Elsa LindbergDovlette". Tijdschrift voor Skandinavistiek 36 (2018): 2, Іо8-г6.

Booth, Marilyn, ed. Harem Histories: Envisioning Places and Living Spaces. Durham: Duke University Press, 2010.

Edrissy, Sulaiman. Burqa Web. http://imgur.com/a/Idjzf.

El Guindi, Fadwa. Veil: Modesty, Privacy and Resistance. Oxford: Berg, I999.

Hayot, Eric. On Literary Worlds. Oxford: Oxford University Press, $20 \mathrm{I} 2$.

Heath, Jennifer, ed. The Veil: Women Writers on Its History, Lore and Politics. Berkeley: University of California Press, 2008.

İnankur, Zeynep, Reina Lewis and Mary Roberts, eds. The Poetics and Politics of Place: Ottoman Istanbul and British Orientalism. İstanbul: Pera Museum, 20I I.

Jerichau-Baumann, Elisabeth. Brogede rejsebilleder. Kjøbenhavn: Forlagsbureauet, I 88I. 
Lewis, Reina. Rethinking Orientalism: Women, Travel and the Ottoman Harem. London: I. B. Tauris, 2004.

Lindberg-Dovlette, Elsa. Kvinnor frän minareternas stad. Vignetter av Isaac Grünwald. Stockholm: Bonniers, I908.

- Främling. Boken om Konstantinopel. Historier om AstridAnisa, Condjagull och Yasmine. Colour illustrations by Einar Nerman. Stockholm: Bonniers, I929 [1924].

—. Bakom stängda haremsdörrar. Stockholm: Bonniers, I93 I.

Loti, Pierre. Les Désenchantées: Roman des harems turcs contemporains. Paris: Calman-Lévy, I906.

MacKenzie, John M. Orientalism: History, Theory and the Arts. Manchester: Manchester University Press, I995.

Oxfeldt, Elisabeth. Journeys from Scandinavia: Travelogues of Africa, Asia, and South America, I 840-2000. Minneapolis: University of Minnesota Press, 20I0.

Peirce, Leslie P. The Imperial Harem: Women and Sovereignty in the Ottoman Empire. Oxford: Oxford University Press, I993.

Roberts, Mary. Intimate Outsiders: The Harem in Ottoman and Orientalist Art and Travel Literature. Durham: Duke University Press, 2007.

Said, Edward W. Orientalism. London: Routledge, I978.

Zilliacus-Tikkanen, Henrika. När Könet började skriva: Kvinnor i finländsk press I77I-I900. Helsingfors: Finska vetenskaps-Societeten, 2005 . 